Eastern Illinois University

The Keep

Faculty Research \& Creative Activity

English

January 2001

\title{
Once upon a Time in Aframerica: The "Peculiar" Significance of Fairies in the Brownies' Book
}

Fern Kory

Eastern Illinois University, fkory@eiu.edu

Follow this and additional works at: http://thekeep.eiu.edu/eng_fac

Part of the English Language and Literature Commons

\section{Recommended Citation}

Kory, Fern, "Once upon a Time in Aframerica: The "Peculiar" Significance of Fairies in the Brownies' Book" (2001). Faculty Research \& Creative Activity. 3.

http://thekeep.eiu.edu/eng_fac/3 


\title{
Once upon a Time in Aframerica: The "Peculiar" Significance of Fairies in the Brownies' Book
}

\author{
Fern Kory
}

Little Annabelle was lying on the laum, a volume of Grimm before her. Annabelle was 9 years of age, the daughter of a colored lawyer, and the prettiest dark child in the village. She had long played in the fairyland of knowledge, and was far advanced for one of her years. A vivid imagination was her chief endowment ...

"I wonder," she said to herself that afternoon, "if there is any such thing as a colored fairy? Surely there must be, but in this book they're all white."

-Fenton Johnson, "The Black Fairy"

The Brownies' Book (January 1920-December 1921) was a groundbreaking but short-lived monthly children's magazine created in part to provide African American children like Annabelle with "colored" fairies. It was the brainchild of W. E. B. DuBois, the only African American founding member of the National Association for the Advancement of Colored People, and since 1910 the managing editor of the NAACP's official organ, Crisis: A Record of the Darker Races. The Brownies' Book grew out of the popular annual "Children's Number" of Crisis, published each October starting in 1912. In this special issue, dozens of photographs of African American children submitted by readers visually framed the usual coverage of political, cultural, and social issues. Each "Children's Number" also included a story explicitly directed to a child audience, either an African folk tale or an original fairy story like the one quoted in the epigraph. ${ }^{1}$

The fact that the first stories offered to children by the editors of Crisis were folktales and fairy stories suggests that these genres were central to their conception of an African American children's literature. This idea is played out even more fully in the Brownies' Book-not just in stories featuring fairies and elves but also in poems (including "Fairies" by Langston Hughes in the January 1921 issue), illustrations, letters from readers, advertisements, and, of course, the magazine's title, which pointedly appropriates a European folk character,

Children's Literature 29, ed. Elizabeth Lennox Keyser and Julie Pfeiffer (Yale University Press, (c) 2001 Hollins University). 
the brownie. But to understand the rhetoric of the choices made by those responsible for first the title and then the content of the Brownies' $B o o k$, it is necessary to understand the literary-historical context in which these choices were made. Only then can we fully appreciate the rhetorical ingenuity of the editors, authors, and illustrators who tried to make a place for African American children in children's literature by revising the materials of mainstream children's literature “' 'authentically,' with a Black difference” (Gates xxii). Specifically, I want to argue that they did so in the Brownies' Book by self-consciously "signifying" on the folk and fairy tale conventions that were an integral part of the Eurocentric pattern of American children's literature.

My terminology here reflects that of Henry Louis Gates Jr. in The Signifying Monkey, in which he discusses the use of "signifying" ("intertextual revision") by African American writers as a culturally specific rhetorical strategy. In this book, Gates focuses his critical lens on revision of previous African American writers by African American writers within that same tradition. But he recognizes that "black writers most certainly revise texts in the Western tradition" (xxii) and that "[a]nyone who analyzes black literature must do so as a comparativist, by definition, because our canonical texts have complex double formal antecedents, the Western and the black" (xxiv). In the context of American culture's conflation of European fairy tale and children's literature, the editors and writers of the Brownies' Book had compelling reasons to respond to the Western canon of children's literature.

By the time W. E. B. DuBois launched his monthly magazine for African American children, fairy tales had come to be seen as the literature of American childhood. This assumption - for it is not quite a fact - is dramatized in literature published by the venerable St. Nicholas Magazine (established 1873) between 1900 and 1920, in which allusions to fairy-tale characters and conventions are common. Such allusions are in fact quietly ubiquitous in poetry, realistic fiction, and even nonfiction published in St. Nicholas during this period. There is a poem about "fairy folk" by a fourteen-year-old boy (November 1919: 90) and a rhymed didactic fairy story by an adult writer ("The Discontented Prince," December 1919: 160). Even more typical are nature poems that allude to "the fairy mists of morn" (November 1919:11) or "fairy forests" (February 1920:329), characters in realistic fictions who describe their benefactor as a "fairy godmother" (November 1919: 62) or describe a friend as like "the anxious sister in the fairy tale" (December 1919: 207), and biographers who declare that a life story 
like Jenny Lind's "reads like a fairy tale" (October 1920: 1077). With some regularity, characters in St. Nicholas say-one way or anotherthat it "sounds like a fairy-story to me" (April 1920: 516).

These allusions to a literature with its roots in European folklore reveal the mutually sustaining relation of mainstream (white) American children's literature and that tradition. As Jack Zipes points out,

by the beginning of the twentieth century, the fairy tale had become fully institutionalized in England and America, and its functions had shifted and expanded. The institutionalization of a genre means that a specific process of production, distribution, and reception has become regularized within the public sphere of a society and plays a role in forming and maintaining the cultural heritage of that society. Without such institutionalization in advanced industrialized and technological countries, the genre would perish, and thus the genre itself becomes a kind of selfperpetuating institute involved in the socialization and acculturation of readers. Thus it is the interaction of writer/publisher/audience within a given society that makes for the definition of the genre in any given epoch. The aesthetics of each fairy tale will depend on how and why an individual writer wants to intervene in the discourse of the genre as an institution. (Introduction xxvi)

The scarcity of original fairy tales and the ubiquitousness of allusions to traditional fairy tales in a cultural institution such as St. Nicholas (which in its heyday in the nineteenth century had published the original American fairy tales of Frank Stockton and L. Frank Baum) ${ }^{2}$ offers evidence that by 1920 these mainstream publishers and writers were not at all motivated to "intervene" in this discourse.

Instead, the unself-conscious Eurocentrism of fairy tale seems to reinforce the racist assumptions of the writers and editors of St. Nicholas, in which African American child characters are almost nonexistent and African American adults function as features of the settings in which white American children act. ${ }^{3}$ This is abundantly clear in St. Nicholas, even when we limit examples to 1920 and 1921, the two years that the Brownies' Book was published. Examples of such static characterizations include the "dark cooks" (October 1920: 1081) who are described as one of the amenities of a private train car in an adventure story, as well as the character in a boarding school story who is described as "Old Tom Juniper . . . the colored man who worked on the place" (May 1920: 627). In an adventure story set in northern Mis- 
sissippi, a young girl who had ridden into town to head off a bandit "threw the reins to a negro who was lounging there" (November 1920: 424), clearly dramatizing the functional subservience of adult African Americans to white children. Conversely, in "Peter to the Rescue" (May 1921), an adult white male revisits his "old plantation home" (636) and finds himself "touched by the ... loyalty" of a "dusky lad" (637) who, though he is only eight years old, helps save his home and his life and seems to feel he was put on earth to do so. In the drawings and photographs and stories they contributed to the "St. Nicholas League," child readers of St. Nicholas marginalize African Americans in the same way. One reader submitted to a contest with a "Homecoming" theme a drawing with an African American porter in the background of a scene set at a train station (June 1920: 762). Another young reader submitted a photo of several unnamed bootblacks (April 1921: 570) to a contest with a "Sun and Shade" theme.

Not all of the racism in children's literature was even this subtle, of course. A 1914 editorial in Crisis analyzes the slippery logic used by the editors of the Youth's Companion to defend their practice of spelling "Negro" with a lower-case $n$ (May 1914: 28-29). And the underlying racism of St. Nicholas became more, not less, pronounced as it entered the 1920s. This is clear in a slapstick comic strip by E. W. Kemble, "The Soft Step," in which an African American adult and child serve as the stereotypical "comic darkies." In this three-panel cartoon an African American mother sneaks up on her "rapscallion" of a son, who is fishing, sitting on a board set across a narrow stream. When she steps "softlike" on the end of it, her son is catapulted safely away from her while she is smacked in the face by the board. The third panel shows her in the stream yelling threats in the estranging dialect common in mainstream literature of this period: "Neber you min', honey! Your mammy gwine ter be home dis ebenin' some time" (August 1920: 898).

Throughout St. Nicholas, various distancing strategies-linguistic, geographic, temporal-insulate its readers from confrontations with contemporary African Americans, even fictional ones. In the index to St. Nicholas for the years up to 1920, many of the stories with African American characters are classified as historical fictions under the heading "Civil War Stories." Others are under the descriptor "Plantation Stories," a category that foregrounds an extreme regional specificity. By depicting African Americans almost exclusively in stories set in the South, the editors elide the "Great Migration" from the South to the North that took place after World War I. And they effectively avoid 
any discussion of "the problem of the color line" (DuBois, Souls 107). The categorization of other stories with African American characters as "Recitations-Negro dialect" segregates whites and blacks linguistically and also reflects the survival of the minstrel tradition into the 1920 s, something that is particularly striking in a 1920 St. Nicholas pageant called "America the Beautiful," which anachronistically represents slaves singing "Swannee" and "longing for the old plantation" (June 1920: 741). As one literary historian notes, "[t]his subconscious acceptance of white superiority was reflected in many books published between 1900 and 1940" (Allen 55). But this consistent evasiveness is particularly noteworthy in the case of St. Nicholas since the editorial stance of the magazine was not apolitical, as evidenced by the fact that it addressed the tensions surrounding immigration editorially and through "Americanization" efforts like the pageant described above.

The fact that many middle-class African American children consumed this propaganda along with the white children who were its implied audience exacerbated the problem. The roster of African American child readers of St. Nicholas who later wrote for the Brownies' Book includes Yolande DuBois, daughter of W. E. B. DuBois (Lewis 458), and Julian Elihu Bagley (Bagley, Welcome, 6). Effie Lee Newsome, a poet who published in Crisis and the Brownies' Book (and after 1921 wrote a children's page for Crisis), as a child read "the Bible, poetry, fairy tales, and children's magazines" (Bryan 802). DuBois's famous statement in "Criteria of Negro Art" (1926) that "all Art is propaganda and ever must be" certainly applies to much of the children's literature of his day. The Broumies' Book is a response in keeping with DuBois's belief that the real problem is "propaganda ... confined to one side while the other is stripped and silent" (66).

In the October 1919 Crisis "Children's Number," DuBois argues that "[t]o educate [our children] in human hatred is more disastrous to them than to the hated; [but] to seek to raise them in ignorance of their racial identity and peculiar situation is inadvisable-impossible" (emphasis mine). Here DuBois's phrasing recalls descriptions of slavery as the "peculiar institution," a powerful reminder that although the institution of slavery has been abolished, African Americans still occupy a "peculiar" place in American society. Significantly, DuBois also suggests that children need to be brought up to understand not just their "racial identity" but also their social-and rhetorical-situation. As a step toward this goal, he proposed the creation of "a little 
magazine for children - for all children, but especially for ours, "the Children of the Sun.' "It will "seek to teach Universal Love and Brotherhood for all the little folk - black and brown and yellow and white" (286). In the same article, titled "The True Brownies," DuBois announced that the magazine "will be called, naturally, The Brownies' Book" (286, emphasis mine). The rhetoric of this choice of title, which DuBois emphasizes by referring to it as natural, responds to a very specific literary-historical context. The brownie is a figure from "Scottish and North of England folklore . .., an elf-like creature, said to come out at night and finish the housework left undone in the day, in return for a reward of milk or cream and food" (Carpenter and Prichard 8586). Given that African Americans figured in mainstream American children's literature of this period almost exclusively as servants, the image of the African American child as the "True Brownie" seems at first to reinforce limiting stereotypes. This seems less true, however, if we look at this decision rhetorically, as an act of African American signification in an oppressive literary-historical context.

As Gates explains, "[t]o Signify . . is to engage in certain rhetorical games" (48). Paraphrasing Roger D. Abrahams, Gates states that in African American usage, "one does not signify something [as in Standard English]; rather, one signifies in some way" (Gates 54, emphasis in original). Another scholar defines signification as "the art of expressing ideas, opinions, feelings, and so forth, by indirection" and as "a culturally specific form of irony": "one signifies on a particular work, author, form, or tradition, by copying central elements of practices, even while revising them in some significant way. The repetition implicit in this form of signifying criticizes or extends the previous and frequently (though not exclusively) white literary or cultural source by setting it within the context of African American expressive culture" (Mason 665). Signification is thus a Bakhtinian doublevoiced discourse in which "[t]he audience . . . is meant to hear both a version of the original utterance as the embodiment of its speaker's point of view ... and the second speaker's evaluation of that utterance from a different point of view" (Morson, quoted in Gates 50, emphasis in original). Of course, it follows that decoding double-voiced discourse requires "shared knowledge" and awareness that "signifying is occurring" (Mitchell-Kernan, quoted in Gates 86). When DuBois addresses his remarks to the adult readers of Crisis in his announcement of the Brownies' Book in 1919, presumably the necessary understanding exists. And because it is one of DuBois's stated goals to prepare Afri- 
can American children to negotiate their "peculiar" rhetorical situation with similar sophistication, he gives their magazine a title that signifies on one of the most visible representatives of American children's culture: St. Nicholas.

DuBois's title signifies on the title (specifically) and through it on the ideology of St. Nicholas, a leading magazine of the dominant culture and therefore a logical parodic analog to the Brownies' Book. Like the Broumies'Book, which reflected the ideology of Crisis, St. Nicholas reflected the ideology of its adult precursor, Scribners' Monthly. It tried to present "life as it is"; however, as one critic points out, "life" seemed to be narrowly defined as "reality as perceived by a well-educated, wellestablished segment of upper-middle-class American society" (Eris$\operatorname{man} 380){ }^{4}$

The title signifies on St. Nicholas by repeating it with a difference, almost literally "a black difference" in this case, given the emphasis on color in DuBois's title. Saint Nicholas, or Santa Claus, was a "wellknown figure" by the early nineteenth century in America and "the only "fairy' that immigrants were to bring over from the Old World" (Avery 2). A jolly, white-haired, pale-faced northern European elf, he brings presents to good children. This makes him a fitting icon for a magazine whose privileged readership is assumed to share northern European descent and to be able to afford to underwrite the activities of this mythical figure.

The brownie, on the "other" hand is, appropriately, a creature with a "dual nature" (Briggs 38)-a phrase that evokes DuBois's idea that African Americans in American society necessarily possess a "doubleconsciousness" that reflects both their own identity and the perception of them by others (Souls 102). Its duality is seen in characterizations of the brownie in literature as an "industrious and helpful household spirit" that is "laborious, grotesque, touchy . . . , capable of affection and even devotion," but also "tricksy, touchy, and easily driven away," capable of "active mischief" and potentially "dangerous" (Briggs 28, 90, 39). This makes the brownie a fitting ancestor of the signifying monkey of Gates's title, who is himself a trickster figure and a symbol of indeterminacy. DuBois's implicit contrast between this earthy and colorful imp and the fat and happy St. Nicholas may well be intended as a double-voiced in-joke between him and the adult readers of Crisis to whom he addressed the remark that his magazine "will be called, naturally, the Brownies' Book." Although the editors of both magazines believed that children like "to now and then ... 
step over to fairy-land" (Dodge 353), DuBois recognized that African American child readers would need a bridge to get from the mainland to a fairy land that would nurture their imaginations.

DuBois's title also probably reflects his awareness of an English children's book by Juliana Horatia Ewing, The Broumies and Other Tales (1865). The first story embedded in this novel's realistic frame story is an anti-fairy tale about brothers who learn that the brownies of folklore are figurative: in reality, "all children are Brownies . . . [w] hen they are useful and considerate" (Ewing 27-28). More than fifty years after its publication, Ewing's story inspired the "adoption of the name 'Brownies' for junior Girl Guides, and the first handbook for Brownies (1920) opened with an abridged version of the tale" (Carpenter and Prichard 86).

The use of the phrase "True Brownies" to refer to his readers suggests that DuBois is familiar with Ewing's book, at least by reputation. The child in that book who goes looking for a "domesticated Brownie" (Ewing 21) to do his chores learns along the way that he and his brother are the only "real" brownies (43). In a relatively straightforward way, the association of helpfulness and personal responsibility with brownies is very much in keeping with DuBois's sense of mission and may well have led to a sympathetic appropriation of this figure for his readers. One of his stated goals in publishing the Brownies' Book is "to inspire [readers] to prepare for definite occupations and duties with a broad spirit of sacrifice" ("True Brownies" 286). And in practice, this idea comes through in the editorial comment attached to a picture from the May 1920 issue showing a group of African American children dressed as fairies for a dancing school performance. The caption describes these children as "truly little fairies," "not the makebelieve fairies of the story book, but real fairies who get lots of happiness out of doing good for others" (May 1920: 153). A story by the poet Georgia Douglas Johnson, "The Story of the Little Tin Horn" (December 1920), has a similar thrust in that the boy hero becomes the "child of all the fairies" because he chooses to share his toys "freely and joyfully" ( Johnson-Feelings 1996, 177). But however sympathetic the appropriation, the claim that African American children are the "true Brownies"-and that the British children in Ewing's tale and frame story or their North American cousins are not-adds a significant edge to this sleight of hand appropriation.

The ubiquitous brownies of author-illustrator Palmer Cox are another context for DuBois's appropriation of this character. The illus- 
trated adventures of Cox's elflike creatures appeared in St. Nicholas from 1883 to 1914 and in numerous books. Attention to this manifestation of fairies in popular culture supports the idea that though the fairy tale retains a basic Eurocentrism in early twentieth-century American children's literature, it has in other ways entered a kind of public domain in which it has been stripped of much of its cultural specificity. ${ }^{5}$ In the case of Palmer Cox's Americanized brownies, it has been commodified as much as it has been adapted.

Cox's books about brownies were a commercial phenomenon. Palmer Cox brownies appeared in magazines and books at first; later they appeared on stage, in a variety of advertisements, and in the form of "toys, games, and educational items" as well as "household articles" (Cummins 101-2). By 1920, the remarkably long heyday of the brownies was largely past. But as one literary historian observes, "eleven [Cox titles] were in print at his death [in 1924], and still drawing a handsome royalty"(Cummins 49). It is difficult to imagine that DuBois was unaware of the creatures Cox described in the foreword to each of his books: "BROWNIEs, like fairies and goblins, are imaginary little sprites, who are supposed to delight in harmless pranks and helpful deeds. They work and sport while weary households sleep, and never allow themselves to be seen by mortal eyes" (quoted in Cummins 62). As Cummins points out, Cox "retained characteristics found in the brownies of folklore, but he made notable changes"; his brownies are "gregarious" and do not "confine themselves to domestic work" though they are willing and able to do "deeds of kindness" (6263). Cox's brownies are not characterized as homebodies, but as travelers, as suggested by the titles of books such as The Brownies Around the World (1894), The Brownies Abroad (1899), and The Brownies in the Philippines (1904). These attributes might all appeal to DuBois's broader, pan-African vision.

Cox's vision, however, did not encompass African American children as implied audience or as subject matter, which is surprising given his emphasis in illustration and text on broadly distinguished "types" of people. Recurring brownie characters included ethnic or national types (an Irishman, an Italian, and an "Indian") as well as characters defined by their profession or lack of same (a policeman, a cowboy, and a "dude" or dandy). All were male. The only dark-skinned character is the Native American. In eliding the African American in his depictions of "the American scene" (quoted in Cummins 51), Cox is following the trend of his era. ${ }^{6}$ Like others of his time, Cox is com- 
fortable mirroring the immigrant heritage of America and mythologizing of the Native American but is either unwilling or unable to portray African Americans.

Through his choice of title, DuBois was signifying on the exclusionary ideology of these "other" brownies and promising the adult readers of Crisis that his magazine for children will rework the most visible materials of popular culture into a mirror that can begin to reflect its child readers back to themselves. Like Cox, DuBois appropriates only the positive aspects of brownies. And he assures the parents of African American children that their children are the "true Brownies," though they were neither included nor imagined as audience or subject by these other authors, who themselves appropriated these traditional characters for their own purposes.

In the twenty-four issues of the Brownies' Book there are numerous works that follow through on the promise of DuBois's title, winking significantly at readers as they intervene in the discourse of American children's literature. From the start, however, DuBois shared editorial responsibilities with Jessie Fauset, the literary editor of the Brownies' Book (and the literary editor of Crisis from 1919 to 1926). In its second year, Fauset officially took over from DuBois as managing editor of the Brownies' Book, though she had probably been responsible for the day-to-day editorial work since the beginning. ${ }^{7}$ DuBois's most obvious contributions to the Browmies' Book during these years included a regular unsigned current events column, "As the Crow Flies," a story ("Honey," a nature fantasy, August 1920), and an essay ("Taboo," May 1921). Fauset put her name to many poems and a story (a translation from the French in April 1920); she also contributed a regular unsigned feature titled "The Judge," in which persona she discusses moral and ethical issues with a set of fictional representative children of various ages.

Given Fauset's role as literary editor, it is almost certainly her voice that is heard most consistently in the magazine, and the stories published in the Brownies' Book reflect her complex literary relationship with fairy tale. On one hand, in the very first "Children's Number" of the Crisis Fauset recommended canonical European fairy tales to African American children as "the first aids to the intellect" and "to the exercise of the imagination" (Crisis, October 1912: 295). And as "The Judge," she focused two columns in the Brownies' Book on the question of what children should read- "the question in comparison with which all other kiddie matters fade into insignificance"-and "of 
course" recommended "fairy tales-Andersen's and Grimm's and the collections of Andrew Lang," as well as "dear 'Uncle Remus'" and a "nice little book published by one of us, - A. O. Stafford's 'Animal Fables of the Dark Continent'" (Brownies' Book, June 1920: 176). In a later column, she recommended Czechoslovakian fairy tales to young readers as well as some other books "by colored writers, mostly about colored people" ( July 1920, 214). In each case the European works are recommended more enthusiastically than those by African American writers on African American subjects.

But on the other hand, in a story serialized in Crisis from August to October 1920, Fauset overtly signifies on fairy tales such as "Cinderella" and "Sleeping Beauty," suggesting that the implicit messages of these tales are particularly dangerous for African American women. The heroine of "The Sleeper Wakes" is a young woman of unknown parentage whose adoptive parents are "colored." She runs away from home as a teenager, under the influence of "fairy tales read to her in those long remote days when she had lived with the tall proud woman" (who gave her up for adoption) and popular movies based on them in which girls who are "pretty" and "poor" marry men who are "tremendously rich" (Fauset 3). She eventually marries her prince, a rich older man with "very white skin" whose "suggestion of power" intrigues her (8). This sleeper only begins to shake off her passivity when her husband threatens a young black servant with violence, at which point she confesses her ambiguous heritage. Months after their subsequent divorce, she discovers that although her ex-husband's love and respect for her has died, his passion for her survives. At that point, she wakes up. Her "youth" and "illusions" (20) die and she comes to see her fairy-tale marriage as a form of prostitution or slavery. She then works to buy herself back from her ex-husband symbolically by reimbursing him for all alimony he paid her. Finally, she decides to move back "home" to her adoptive family and vows to throw in her lot with colored people.

This fable makes a strong statement about the ways canonical and popular narratives are "not always true to life" (4) and points out that African American women who attempt to participate in these cultural narratives are particularly vulnerable to being misread. The narrator explains that when the protagonist's husband thought she was poor and white, it was "just the kind of romantic story to appeal to a rich powerful man" (9). But when her husband believes she is poor and black, the story turns out to be about sex. This story offers evidence 
that Fauset-perhaps as a result of her months as literary editor of the Brownies' Book-is rethinking how fairy tales affect African American readers. ${ }^{8}$ But the fact that she published it in Crisis and not in the Brownies' Book suggests that Fauset thought that the story was not appropriate for the Brownies' Book audience of "Kiddies from Six to Sixteen."

It is difficult to gauge with certainty the effect Fauset's ambivalence about fairy tales had on individual stories published in the Brownies' Book. It is indisputable, however, that under her literary editorship the magazine regularly published what one reader referred to as "splendid stories about fairies" (August 1920: 256). These innovative stories offered readers a change from the overt didacticism of the nonfiction written specifically for African American children at this time, ${ }^{9}$ though the Brownies' Book also built on that tradition, regularly including biographical sketches of contemporary and historical African American adults and children. But the editors also expanded the canon of African American children's literature in many directions by including stories, plays, and poems written specifically for children and, in a number of cases, by children. ${ }^{10}$ Before the Broumies' Book, fiction for African American children was rare and fantasy-outside of folklore-equally unusual, even including the experiments in this form in three of the annual "Children's Numbers" of Crisis that preceded the Brownies' Book.

As we've seen, in 1920-21 St. Nicholas, though full of allusions to European fairy tales, rarely published fairy stories. The fairy stories published in the Brownies' Book, on the other hand, were original stories in which authors and illustrators tried to use the characters and conventions of fairy tale " 'authentically,' with a Black difference" (Gates xxii). But their success at evading the rhetorical traps behind the transparent assumptions of the dominant culture is mixed, at least partly because the expectations of the readers-and writers-of the Browmies' $B o o k$ had been formed by their reading of literature written for white children. ${ }^{1}$ As Gates notes, when faced with "a deafening silence in black literary antecedents" (133) authors sometimes have to fit their vision into generic shapes taken from white literary traditions. Looking at the use of fairy-tale characters and conventions in some of the original stories published in the Brownies' Book offers a fascinating glimpse into the opportunities and pitfalls of this peculiar rhetorical situation.

For example, the first story in the first issue of the Brownies' Book 
- "Pumpkin Land" (January 1920) by Peggy Poe-and its sequel"The Watermelon Dance" (September 1920) - are a problematic hybrid of the most didactic sort of fairy story and a conventional plantation story. ${ }^{12}$ The central character, Happy, is "a little colored boy" who lives with his Mammy in the "Land of Sure-Enough, away down South, in a most wonderful land named Georgia" (3). In the secondary fantasy world embedded in this domestic frame, we meet conventional nature characters - "Mister Bumble Bee" and "Mister Rabbit"as well as the allegorical "Mister Temp-ta-tion" and an "elf," "Pumpkin Man" (4). The stories convey the presumably harmless overt moral of the blandest sort of children's story (one should always "T-R-Y"). But they eventually betray their plantation roots through each tale's external focalization - the way the narration looks at the child Happy and not from his perspective - and its naive narratee, for whom the South is a foreign country. Both of these features could, however problematically, merely reveal the urban northern bias of this pre-Harlem Renaissance magazine. But the distance between the child reader and the child subject of these stories turns perverse when Happy is described as seeing someone the text refers to as "Captain Jones' colored boy" (6). If Happy were white (as we find out in the second story his two little friends are), the story's narrational perspective would make more sense.

There are other stories that betray a lack of editorial self-consciousness about the baggage carried by the characters and conventions of fairy tale, as we can literally see in the sentimental one-act play "Tommy and the Flower Fairies" by Eulalie Spence. The protagonist is described in the culturally generic text as "Eight year old Tommy ... the much spoiled and petted only child of wealthy parents" (April 1921, 122). The full-page illustration by Hilda Rue Wilkinson, a regular contributor, shows an African American child in a sailor suit waking (within his dream) to find himself surrounded by stereotypically pale fairies with long straight blonde hair. The frontispiece to a later issue of the Brownies' Book-a photograph of a group of African American school children from Birmingham, Alabama, who performed this play -highlights the inappropriateness of this image to a script for African American children (December 1921). To compound matters, this illustration appears only a few pages before an advertisement for "Madame C. J. Walker's Superfine Preparations for the Hair and for the Skin," which are touted as "The Gift of the Good Fairy" to "unfortunate ones whom nature had not given long, wavy hair" (back cover). 
But there are many other tales that exhibit more self-consciousness about their role in a magazine dedicated to enhancing the self-esteem of African American children. For example, the illustrations for "The Fairies' Flower Garden" (May 1920: 131), an otherwise culturally generic story, include both children and fairies of color. The issue of color is addressed both visually and textually in the story "Dolly's Dream" (November 1920) by Nora Waring, in which the main character's fairy godmother grants her wish to have "long, golden curls" instead of her " "cwinkley" . . black ringlets." Dolly learns to regret this wish because no one recognizes her after the change, which also changes her "little, dimpled face of rosy tan" to "pinky white skin" and leaves her with the "blue, blue eyes" of her favorite doll (JohnsonFeelings 1996, 42). By the end, Dolly exclaims with dismay "I'm not me" and finds she desperately wants to change back so her friends and relatives "will always know [her]" (43), a resolution that hints at the interconnectedness of personal, familial, and racial identity.

In the last issue of the Brownies' Book, in a story called "The Land Behind the Sun" by Yolande DuBois, the female protagonist exclaims in surprise "Why! . . , everybody's brown" when she sees the darkskinned inhabitants of this fairyland in her dreams. Her fairy escort, a lady-in-waiting named Topaz, tells Madalen that "we are the Brownies -we are all brown, even our Queen" (December 1921: 332). This young woman's surprise dramatizes the need of African American children to hear the implicit message of these stories - that the symbolic power and beauty and nobility of fairies need not be tied exclusively to whiteness.

In spite of their differences, these stories illustrate one of the most common narrative strategies used by African American writers of fairy stories for the Brownies' Book: they make the fantasy itself part of a dream and embed it in a domestic frame in which realistic African American children are the leading characters..$^{13}$ The most significant advantage of this framing was that it inscribed contemporary African American children in children's literature-something mainstream children's literature had not even tried to do-thus making good on the promise implicit in DuBois's title. The frame also offered readers contemporary African American child characters they could relate to more directly than to fairies, even brown ones. And though the frame offered the reassuring return to reality typical of domestic fantasies, it often functioned additionally as an opportunity for the author to offer a call to action in the real world. In these stories, the readers of the 
Brownies' Book are encouraged to become the "true Brownies," energized by the "Joy! Love! Hope!" (April 1921, 124) that will allow them to contribute to the advancement of the race, as Tommy is ready to do after his dream of the flower fairies.

The framed story that offers the Brownies' Book's most sophisticated rhetorical model for fledgling "New Negroes" is "The Story-Telling Contest" by Julian Elihu Bagley, in which Bagley signifies on European fairy tale and offers readers a vision of a living African American folk tradition to take its place. ${ }^{14}$ Bagley wrote five stories for the Broumies' Book, all with the same basic frame tale: little Cless comes to his Granny with a problem, in response to which she tells him a story, which he learns from her and later retells. There are several interesting features to this frame. The first is that Cless and his grandmother live in a Harlem apartment on 135th Street (November 1920: 323). (Cless's father is in Florida working at a Palm Beach hotel; no information about his mother is provided.) But the tales that grandmother tells are set in the South - a swamp in Virginia, for example (as in "How Br'er Possum Learned to Play Dead," January 1921) - or in Africa (as in "How Mr. Crocodile Got His Rough Back," November 1920) or in the less clearly defined "land of sunshine" (as in "Once 'Twas a Little Pig," June 1921). Thus, the setting of the frame tale and the settings of the embedded tales work together to tie the contemporary urbandwelling African American child represented by Cless to his or her roots in the American South and Africa, even as they evoke fantasy and distance.

In "The Story-Telling Contest" (November 1921, 303), a Thanksgiving story that appeared in the penultimate issue of the Brownies' Book, Granny tells Cless "a story that will just fit in for the contest," a story the reader does not "hear" until later in the story when Cless tells it to his classmates during the contest. In the context of Bagley's story, the European fairy tales told by the children who precede Clesswhich include "The Three Bears" and "Little Red Riding Hood"--are boring stories that are "old as the hills." Cless wins the contest because he tells "a really new story" (emphasis in original). This "new" story, modeled on African American folktale, centers-as the storytelling contest does - on the question of who will get the prized turkey drumstick. Cless's story begins "Once a long, long time ago, the day before Thanksgiving, Br'er Bear, Br'er Fox, Br'er Rabbit and Br'er Wolf met together to lay plans for their Thanksgiving dinner." Cless's story, in which Br'er Rabbit the trickster successfully appropriates the drum- 
stick, has the room "literally roaring with applause," in contrast to the "groans" that greeted the anemic, twice-told European tales. Cless, as a result, wins the turkey drumstick, which he wraps up to take home to Granny.

In this story and in the others Bagley published in the Brownies Book, Granny's tales are presented as part of a living oral tradition; they are, paradoxically, "new," though they are presented to Cless as if they were preexisting tales. It is clear, however, that Granny is making up these stories rather than remembering them because each is tailored to Cless's particular situation. Granny's insistence on telling Cless "the best [story] for Thanksgiving Day" and not, as Cless requests, "the best for any day" shows that Granny is self-conscious about her own rhetoric, as Gates suggests that African Americans have had to be (xi) and as the "peculiar" rhetorical situation of the writers for the Brownies' Book demanded they be. And in each story, Bagley shows Granny using her rhetorical flexibility to empower her grandson as a teller of African American folktales. In the same way, Bagley's tale empowers Cless's peers, the readers of the Brownies' Book, by giving them tellers of African American folktales as role models. This valorization of the African American folk tradition would become a major thrust of the Harlem Renaissance just a few years later and would be associated especially with writers such as Zora Neale Hurston, who in "Characteristics of Negro Expression" (1934) said, "Negro folklore is not a thing of the past. It is still in the making. Its great variety shows the adaptability of the black man: nothing is too old or too new, domestic or foreign, high or low, for his use" (84). She also observed that "it is obvious that to get back to original sources is much too difficult for any group to claim very much certainty. What we really mean by originality is the modification of ideas" (86). This observation is in line with Gates's sense of how African American writers signify, by "repeating received tropes and narrative strategies with a difference" (217).

Bagley's story does not just signify on European fairy tale; it also repeats the narrative strategies of Joel Chandler Harris's Tales of Uncle Remus (1880) with a significant difference. The African American folktales collected and published by this white journalist as "Uncle Remus" stories were embedded in a plantation frame in which the tales are told to amuse and instruct a young white boy. Bagley signifies on Harris's Uncle Remus by replacing him with Granny, an African American woman who adapts her tales to the needs of a contemporary African American boy instead. Bagley's adaptation of features old, new, 
domestic, foreign, high and low allows him to signify successfully on European fairy tale - itself "an appropriation [of] oral storytelling tradition" (Zipes, Introduction xii)-while simultaneously intervening in Joel Chandler Harris's similar appropriation of African American folklore. In the process, Bagley clearly directs African American children back to their cultural roots and their elders, presciently pointing to the vernacular tradition as the most flexible tool available to the "New Negro."

Dianne Johnson-Feelings has rightly called the Brownies' Book an "experiment in pedagogy and propaganda aimed at African-American youth" $(1996,336)$. It was undertaken in the middle of an exciting time for mainstream children's literature: 1919 saw the first National Children's Book Week and the establishment of the first children's book department at a major publisher. The Newbery Medal was established in 1922. It was an exciting time for Aframerica too, a crisis time, following as it did the race riots and lynchings of the "Red Summer" of 1919. The Brownies' Book was created at the intersection of these moments. When we look closely at one set of experiments contained within the Brownies' Book-those involving re-visions of folk and fairy tale motifs - the complexity of the rhetorical situation in which African American writers wrote becomes clearer and we can appreciate the way they meet the challenge offered by an institutionalized European fairy tale and avail themselves of "the new possibilities of subversion" (Zipes, Introduction xvi) it offers.

"Children's literature" always entails a complex rhetorical relation between the child reader and the adults who write, edit, and publish literature for children, a relation that is further complicated by the layer of adults - parents, teachers, librarians, and so on - who provide children with much of their access to literature. This rhetorical imbalance has led theorists such as Jacqueline Rose to posit the fundamental impossibility of children's literature. But for writers of African American children's literature, the need to subvert the subtle and not-so-subtle messages of a body of racist children's literature inspired them to try innovative strategies to bridge these rhetorical gaps. Writers and illustrators for the Brownies' Book revised the materials of mainstream American children's literature in order to create something "new" that would allow African American children-the newest Negroes - to win the storytelling contest in spite of the fact that everyone else was telling the same old story. The twenty-four issues of the Brownies' Book are the site of the rhetorical struggle over fairyland that 
W. E. B. DuBois began with his choice of title. Close attention to the rhetoric of these tales reveals the complexity of the peculiar situation in which early twentieth-century African Americans found themselves decades after the "peculiar institution" of slavery was abolished.

\section{Notes}

The author gratefully acknowledges the assistance of Ruth Hoberman, who read multiple drafts of this essay, and the Council on Faculty Research at Eastern Illinois University.

1. In this essay I use the term folk tale to refer to the tales in the Crisis "Children's Numbers" and the Brownies'Book that are presented to the reader as oral tales told within a specified culture. This terminology is in line with Zipes's description of folktale as a term that "clearly signifies that the people were the carriers of the tale" (Breaking 23, emphasis in original). My choice also reflects the practice of the editors of the Brownies' Book, who offered this comment in the introduction to a Ugandan folktale published in the second issue: "the story is very old and has come down from father to son for many generations and has probably met with almost no changes. Such a story is called a folk tale" (February 1920: 46). I also follow both Zipes and the editors of the Brownies' Book in using the term fairy tale to refer to "literary" versions of specific European tales "adapted by bourgeois or aristocratic writers in the seventeenth and eighteenth centuries . . . for educated audiences" (Zipes, Breaking 23, emphasis in original).Jessie Fauset, literary editor of the Brownies' Book, specifically recommends "fairy tales" of this description in a June 1920 column (176) quoted below. My use of the term fairy story is more idiosyncratic but, I hope, useful for distinguishing from these traditional tales the original stories published in the Brownies' Book that borrow some of the generic characters of folk and fairy tale - specifically brownies, elves, fairies, and fairy godmothers - without reference to their roots in any specific culture or their previous appearance in specific tales.

2. L. Frank Baum in his 1908 preface to American Fairy Tales (1901) promised "to offer our wide-awake youngsters modern tales about modern fairies" (ix) and set the first tale "on Prairie avenue in Chicago" (15). Baum's American Fairy Tales are not consistently American in setting, however, and his only story featuring "black people" is set in Africa, "[o]n one of the upper branches of the Congo river" (Baum 94, 93). This displacement of African Americans by Africans is another example of the pattern of evasion and elision of African Americans in mainstream American children's literature of the early twentieth century.

3. Critics including Violet Harris have already demonstrated that the Brownies' Book "challenged a selective tradition in children's literature" that "provided children with pejorative portraits of Black culture and Black people" (4) and "reflected the values and power of the gentry class" (10), excluding African Americans. Harris has given the most sustained attention to the Broumies' Book in her dissertation, The Brownies' Book: Challenge to the Selective Tradition in Children's Literature. Some of her core ideas are also presented in "Race Consciousness, Refinement, and Radicalism." But the first scholar to contribute to the literature was Elinor Sinnette in "The Brownies' Book: A Pioneer Publication for Children." Sinnette was also the first to compare the Brounies' Book to St. Nicholas magazine. Courtney Vaughn-Roberson and Brenda Hill offer another comparative approach in The Brownies' Book and Ebony Jr! Dianne Johnson-Feelings has not only given scholarly attention to the Brownies' Book in Telling Tales, with noteworthy attention to the importance of its illustrations, but has also recently made it available to a new 
generation of readers in The Best of The Brownies' Book (1996). This anthology contains an impressive number of selections from the twenty-four issues of the magazine and a complete facsimile of the April 1921 issue from front cover to advertisements.

4. In its own way, the Broumies' Book too represented the views of its well-educated editors (both DuBois and Fauset had advanced degrees) and the largely middle-class readership of Crisis, a group DuBois referred to collectively as the "talented tenth" of contemporary African American society. It has also been pointed out that much of the fiction in the Brownies' Book, perhaps self-consciously, presented atypically affluent African American families (Harris, Brownies' Book, 112-14, 221-25).

5. There is evidence that by 1920 titles in the canon of traditional European fairy tales were no longer clearly associated in the popular mind with the specific cultures or authors that produced them. For example, in one early twentieth-century American series book by Inez Haynes Irwin, the children who buy inexpensive books of "fairy tales" from Maida's Little Shop (1909) get an undifferentiated mix of English, French, and German tales including "The Three Little Bears," "Puss-in-Boots," "Jack-and-theBeanstalk," "Jack the Giant Killer," "Cinderella," "Bluebeard," "Little Goody-TwoShoes," "Tom Thumb," "The Sleeping Beauty," and "The Babes in the Wood."

6 . The same is true of the Maida books (cited above), in which there are many Irish American characters but the only adult African American characters are servants and the closest thing to an African American child is a "statue of a negro boy with his arms lifted above his head [who] seemed to beg the honor of holding the reins" (Irwin 19). This example is particularly poignant because Effie Lee Newsome, writing in Crisis about a recent reprint of Maida's Little Shop, thought she detected African American characters in it (October 1927:260), mistakenly over-reading a description of two brown-eyed Irish immigrant children who were compared to "brownies" (Irwin 71).

7. Carolyn Wedin, author of the only book-length biography of Jessie Fauset, claims that "Fauset wrote hundreds of signed and unsigned stories, poems, dialogues, biographies, and articles, as well as handling all of the correspondence with contributors and all of the editing" (337). As literary editor of these two publications Jessie Fauset nurtured many of the young talents who would contribute to the Harlem Renaissance, including Langston Hughes, who published in both Crisis and the Brownies' Book during these years, and Nella Larsen. Hughes would later call Fauset one of the "midwives" of the "New Negro Renaissance" (218). In many ways, the Brownies' Book is a defining project of the Renaissance. In addition to soon-to-be-famous writers such as Hughes, Larsen, and Fauset herself (who published one of the first novels of the Harlem Renaissance in 1924), contributors included Laura Wheeler Waring (one of many African American artists), folklore scholars Arthur Huff Fauset (Jessie's half-brother), Elsie Clews Parsons, and A. O. Stafford, and a host of less well-known writers, including child reader-writers such as Bertie Lee Hall and John Bolden.

8. This story can be seen as a study for Fauset's novel Plum Bun (1929), the plot of which is structured ironically around a nursery rhyme ("To market, To market ...") and signifies on fairy tale and romance conventions (for more on this see Deborah McDowell's 1990 introduction to the Beacon Press "Black Women Writers" edition of Plum Bun). See also her earlier Crisis story (serialized in April and May) "There Was One Time," the story of a "typical American girl done over in brown" (April 1917:273) who takes a day off from teaching to live out a story from a French "fairy-tale" (272).

9. An advertisement for some of the books available to African American children appears on the inside back cover of many issues of the Brownies' Book (including the April 1921 issue, available in facsimile in Johnson-Feelings 1996). There is some poetry by Paul Laurence Dunbar on this list and one realistic novel: Hazel by Mary Ovington White, a white woman who was one of the founders of the NAACP. Nonfiction offerings include History of the Negro by Benjamin Brawley, The Negro by DuBois, The Negro 
in Literature and Art by Brawley, and A Child's Story of Dunbar by Julia Henderson. For more extensive information on the history of African American children's literature, see Johnson-Feelings's "Children's and Young Adult Literature."

10. The editors comment that "there wasn't a market for our stories and biographies and poems, but now we have THE BROWNIE's Book and 'Little People of the Month" " as a forum "for each little Brownie who succeeds" (November 1920: 349). This choice is connected to the magazine's mission of providing its readers material they can read "with pride" and, in DuBois's terms, "emulation" (Crisis, October 1919: 286). In order to press home this point, the story "A Visit to Fairyland" by Bertie Lee Hall is accompanied by a picture of its young female author (February 1920: 37). This is one of twentyfive photographs of African American children in the first issue of the magazine alone. There is also a photograph of John Bolden, who "adapted" "The Three Golden Hairs of the Sun-King" (September 1920: 276). This treatment contrasts with that of child writers in St. Nicholas, in which children's contributions were relegated to the back of the magazine and published in smaller print. Contributions to the Brownies' Book were integrated into the magazine and illustrated by the same artists who embellished the works of adult writers. This empowering of child readers is another feature of the Brownies' Book that was prefigured in the earlier "Children's Numbers" of Crisis: the October 1914 story "The Fairy Good Willa" was written by a ten-year-old child.

11. Children whose letters were published in "The Jury" commented on their enjoyment of its fairy stories (November 1920: 350). On the evidence of the letters they sent to the Brownies' Book, readers participated in the general understanding of the conventional features of fairy tales. One reader says she can imagine "all the princesses in the fairy-tales standing tall and white in the corners" and refers to specific characters such as "Tom Thumb," "Puss in Boots," and "sister Anne - she was Bluebeard's wife's sister, you know" (September 1920: 282). A child in a story by an adult writer imagines that a friend is "a beautiful lady in distress" and that a cow is "a ferocious dragon ready to spring on her"; he is "an armoured knight" (November 1920: 329). Fauset herself structured one of her columns around young Billy's wish "that a fairy would come along and give [him] three wishes" so that children wouldn't have to go to school any more (April 1921; Johnson-Feelings 1996, 108).

12. Violet Harris has also commented on Poe's stories as "analogous to the plantation image" (Brownies'Book 226). Saul identifies Poe as one of the authors and illustrators who had already contributed to the Crisis before writing for the Brownies' Book (60).

13. This explains why Violet Harris found only five "self-identified" folk or fairy tales to discuss in her study of the Brownies' Book (243-246): "others that contained the elements of fairy tales were categorized as stories" (244).

14. Bagley (who died in 1981 at age eighty-eight) published a children's book in 1971 that contained illustrated versions of some of these stories and others without a frame story. One of many forgotten Harlem Renaissance writers, he also published in The Southern Workman and Outlook before the Broumies'Book, and for Crisis and Opportunity during the 1920 s.

\section{Works Cited}

Allen, Marjorie N. One Hundred Years of Children's Books in America. New York: Facts on File, 1996.

Avery, Gillian. Behold the Child: American Children and Their Books, 1621-1922. Baltimore: Johns Hopkins University Press, 1994.

Bagley, Julian Elihu. Candle-Lighting Time in Bodidalee. New York: American Heritage Press, 1971. 
Welcome to the San Francisco Opera House. Interview by Suzanne Riess. Berkeley: Bancroft Library Regional Oral History Office, 1973.

Baum, L. Frank. American Fairy Tales. 1901. New York: Dover, 1978.

Briggs, K. M. Fairies in Tradition and Literature. London: Routledge and Kegan Paul, 1967.

Bryan, T. J. "Effie Lee Newsome." In Notable Black American Women. Ed. Jessie Carney Smith. Detroit: Gale Research, 1992. Pp. 802-4.

Carpenter, Humphrey, and Mari Prichard. "Brownie." In Oxford Companion to Children's Literature. New York: Oxford University Press, 1984.

Cummins, Roger W. Humorous But Wholesome: A History of Palmer Cox and the Brownies. Watkins Glen, N.Y.: Century House Americana, 1973.

Dodge, Mary Mapes. "Children's Magazines." Scribner's Monthly, July 1873: 352-354.

DuBois, W. E. B. "Criteria of Negro Art." In Within the Circle: An Anthology of African American Literary Criticism from the Harlem Renaissance to the Present. Ed. Angelyn Mitchell. Durham, N.C.: Duke University Press, 1994. Pp. 60-68.

- The Souls of Black Folks. 1903. In Oxford W. E. B. DuBois Reader. Ed. Eric J. Sundquist. New York: Oxford University Press, 1996.

"The True Brownies." Crisis, October 1919: 285-86.

Erisman, Fred. "St. Nicholas Magazine." In Children's Periodicals of the United States. Ed. R. Gordon Kelly. Westport, Conn.: Greenwood Press, 1984: 377-88.

Ewing, Juliana Horatia. The Brownies and Other Tales. 1865. London: G. B. \& Son, 1927.

Fauset, Jessie. "The Sleeper Wakes." Crisis, August-October 1920. Also available in The Sleeper Wakes: Harlem Renaissance Stories by Women. Ed. Marcy Knopf. New Brunswick: Rutgers University Press, 1993: 1-25.

Gates, Henry Louis. The Signifying Monkey: A Theory of African-American Literary Criticism. New York: Oxford University Press, 1988.

Harris, Violet. “The Brownies' Book: Challenge to the Selective Tradition in Children's Literature." Ph.D. Diss., University of Georgia, 1986.

- "Race Consciousness, Refinement, and Radicalism: Socialization in The Brownies' Book." Children's Literature Association Quarterly 14, no. 3 (winter 1989): 192-96.

Hughes, Langston. The Big Sea. 1940. New York: Hill and Wang, 1963.

Hurston, Zora Neale. "Characteristics of Negro Expression." In Within the Circle: An Anthology of African American Literary Criticism from the Harlem Renaissance to the Present. Ed. Angelyn Mitchell. Durham, N.C.: Duke University Press, 1994. Pp. 79-94.

Irwin (Gilmore), Inez Haynes. Maida's Little Shop. New York: Grosset and Dunlap, 1909. Johnson, Fenton. "The Black Fairy." Crisis, October 1913: 292-94.

Johnson-Feelings, Dianne. "Children's and Young Adult Literature." In the Oxford Companion to African American Literature. Ed. William L. Andrews, Frances Smith Foster, and Trudier Harris. New York: Oxford University Press, 1997. Pp. 133-40.

. Telling Tales: The Pedagogy and Promise of African American Children's Literature. Westport, Conn.: Greenwood Press, 1990.

- ed. The Best of The Brownies' Book. New York: Oxford University Press, 1996.

Lewis, David Levering. W. E. B. DuBois: Biography of a Race. New York: Henry Holt, 1993.

Marcus, Leonard S. "Mother Goose to Multiculturalism: Through More Than a Century of Change and Growth, Children's Book Publishing Remains a Cyclical Business." Publisher's Weekly 244, no. 31 (July 1997): 62+.

Mason, Theodore O., Jr. "Signifying." In Oxford Companion to African American Literature. Ed. William L. Andrews, Frances Smith Foster, and Trudier Harris. New York: Oxford University Press, 1997. Pp. 665-66.

Newsome, Effie Lee. "Child Literature and Negro Childhood." Crisis, October 1927: $260+$.

Rose, Jacqueline. The Case of Peter Pan, or The Impossibility of Children's Literature. 1984. Philadelphia: University of Pennsylvania Press, 1993. 
Saul, E. Wendy. “The Brownies' Book.” In Children's Periodicals of the United States. Ed. R. Gordon Kelly. Westport, Conn.: Greenwood Press, 1984. Pp. 62-68.

Sinnette, Elinor. "The Brownies' Book: A Pioneer Publication for Children." Freedomways 5 (winter 1965): 133-42.

Vaughn-Roberson, Courtney, and Brenda Hill. "The Brownies' Book and Ebony Jr.! Literature as a Mirror of the Afro-American Experience." Journal of Negro Education 58, no. 4 (fall 1989): 494-510.

Wedin, Carolyn. "Jessie Redmon Fauset (1882-1961)." In Notable Black American Women. Ed. Jessie Carney Smith. Detroit: Gale Research, 1992. Pp. 336-40.

Zipes, Jack. Introduction to Spells of Enchantment. Ed. Jack Zipes. New York: Viking, 1991. Pp. xi-xxxii.

Breaking the Magic Spell. Austin: University of Texas Press, 1979. 